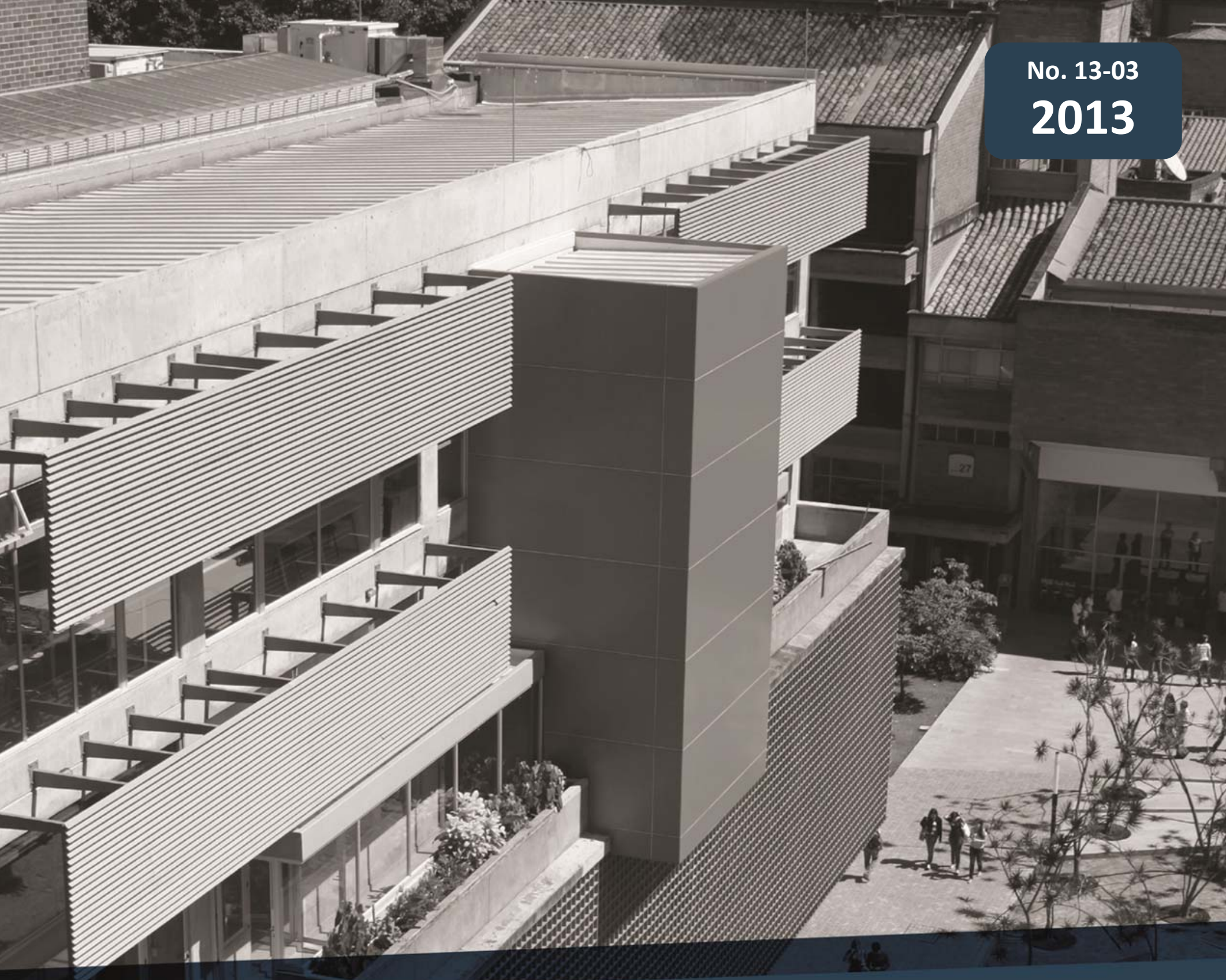

AN INTERNATIONALIZATION MODEL TO ENTER THE NORTHERN TRIANGLE MARKET

Carolina Marín Cadavid

John J. García

Documentos de trabajo

Economía y Finanzas

Centro de Investigaciones Económicas y Financieras (CIEF)

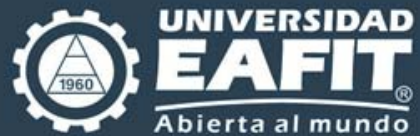




\title{
An Internationalization Model to Enter the Northern Triangle Market
}

Carolina Marín Cadavid*

John J. García**

\begin{abstract}
An internationalization model is proposed for a Colombian company specialized in design and consulting engineering services related to the energy sector. The study of these services is relatively new in internationalization and competitiveness, therefore of great interest for research purposes. The model is created with the purpose of conquering the Northern Triangle market (Guatemala, Honduras, El Salvador). Different internationalization theories, such as the Eclectic Paradigm, the Uppsala Model and the Five Competitive Forces were considered. Different assessments were carried out based on qualitative and quantitative data through the case study method in which analyses were performed to generate and evaluate the main variables in the model. Outcomes assure that, HMV Ingenieros Ltda (a Colombian company) is prepared to start commercial presence in the Northern Triangle considering the Step-by-Step model as the way to reach the studied market. In addition, analysis of macroeconomic trends finds Guatemala as the best potential market.
\end{abstract}

Key words: Internationalization, engineering services, Northern Triangle Market, case study, the Step by Step Model (proposed).

JEL Classification: F14, F23, R31.

\footnotetext{
* Msc in International Business, Professor in Department of Economics and Administration, Universidad de Medellin Adress: carrera $87 \mathrm{~N}^{\circ} 30-65$ (Medellín, Colombia). Telephone: (+574).3405555 E-mail: cmarinc@udem.edu.co

** Ph.D in Economics, Professor Department of Economics, Universidad Eafit (Colombia). A. A. 3300

Medellín (Colombia). Telephone: (+574)2619549, Fax: (+574)2664284. E-mail: jgarcia@eafit.edu.co.
} 


\section{Introduction}

Currently, there are many theories that explain the different processes followed by companies in order for them to internationalize. Given the economic globalization, where markets are increasingly more competitive, firms have experienced the need to establish multimarket contact strategies, with their own services and even creating new ones in different markets in order to maximize their benefits. The energy services sector in Colombia has evolved from local to regional services. According to Ruiz (2010), multilateral negotiations have been successful; hence, have generated bilateral agreements for the regional energy integration.

In Colombia, the internationalization of the energy services started by taking advantage of the psychic distance Principle and exporting to neighbor countries such as Ecuador, Peru and Venezuela. Likewise,the globalization has promoted the export of services to developing countries, which results in opportunities to diversify services related to foreign direct investment (FDI). The latter has been the preferred entry mode in Latin America to reach other markets (Bastidas et al., 2008 and Primo, 1996).

After analyzing the previous statements, our research question is: What are the steps that HMV Ingenieros Ltda should follow to offer their design and consulting engineering services in the Northern Triangle market?

This research analyzes the internationalization process that a design and consulting engineering services (related to the energy industry) company, HMV Ingenieros Ltda, should follow in order to provide services in the Northern Triangle.

The methodology followed is the case study, and descriptive variables considering various internationalization theories; the eclectic paradigm proposed by Dunning (1980), the Uppsala model by Johanson and Vahlne (1977), and entry modes in services.

Results suggest that HMV Ingenieros Ltda experience is a key factor in the internationalization process of providing consulting and design services (related to energy). In this case, the company has a strong potential to establish commercial presence (mode 3 ) in The Northern Triangle Market. By analyzing the macroeconomic variables of these three countries, it is possible to conclude that the markets with the greatest growth potential are Guatemala followed by Honduras, and finally, El Salvador.

The present work also analyzes HMV Ingenieros Ltda experience in Peru and Chile, as a reference process to penetrate the Northern Triangle Market, and identifies strategies they have used to enter the latter markets. A complete market characterization of the Northern Triangle is described according to the entry mode subsidiary through Greenfield strategy.

Finally, it examines the dynamics and internationalization processes in order to generate a model that could serve as point of reference to other service companies of the same sector looking to explore similar markets.

\section{Literature Review}

In Latin America the internationalization processes of the engineering services have been supported by local engineering services multinationals, which have previously established Merger and Acquisitions (M\&A) and Joint Ventures (Rudnick, 1998 and Fernandez-Stark et 
al., 2010). Although Greenfield operations in partnership with local companies are not common, it certainly is a way to expand operations and to take competitive advantage of local talent in engineering.

The competitive advantage that Latin American companies have in the design and consulting engineering services sector is the low labor cost combined with an appealing talent in this area (Fernandez-Stark et al, 2010), and relatively low demand for such services in the local market. Specifically, Colombian companies such EPM, ISA, among others, have started projects in countries like Panama, Peru, Ecuador, Bolivia and Venezuela. Colombia has also ventured into other markets through immigrant engineers and professionals who have moved and served abroad.

With 50 years of experience, HMV Ingenieros Ltda is a private company originated in the merge of different companies (Hidroestudios S.A and Mejia Villegas S.A. in 2000). Hidroestudios S.A, founded in 1960, is specialized in civil engineering, environmental studies, hydro generation, and infrastructure projects. While, Mejia Villegas S.A, created in 1973, built its experience and skills in the energy service sector (HMV Ingenieros Ltda, 2008). This fusion with more than 1200 employees has carried out more than 1500 design projects and consultancy, engineering and turnkey solutions, and more than 45 million man / hours worked in engineering.

Before these two companies merged, they already had enough international experience, especially in the Andean and Central American countries, but at the moment they are not active in the Northern Triangle Market.

\subsection{Services contextualization}

There are many ways to describe the engineering services. The United States Census Bureau (U.S. Census Bureau, 2012), for instance, considers design, consulting and assistance services to others, regarding environmental design and construction of buildings and structures as included in such definition. On the other hand, Datamonitor report (2009) considers that design services, consulting, and contracting related to the energy sector, also include civil engineering firms, except housing construction.

This paper focuses on the design and consulting services related to energy and the services offered by HMV Ingenieros Ltda to enter the Northern Triangle market.

\subsection{Theories of internationalization}

To support the ideas previously expressed, different theories are used in this study. The Production Eclectic Paradigm developed by Dunning (1980), who examined the reasons why a firm first begins international operations based on its ownership advantages, second, profits from the locational-specific advantages of the foreign markets throught the FDI including the knowledge gained in the production process of the same services with the purpose of acquiring companies or explore international markets, and third gets Internalization advantages. All of them constitute the so- called OLI paradigm.

Dunning (1980) believes that a company has to be able to add value to inputs and then estimate the possibility of taking them out as outputs. Thus, two types of inputs are identified: 
the first are those which are available, on the same terms, to all firms regardless their size or nationality, but which are specific to particular locations and have to be used in the same location. The second input is defined as one in which a company creates its own inputs through technology and organizational skills.

For the Uppsala Model described by Johanson and Vahlne (1977), operations performed in the new markets are explained by companies that follow the step by step internationalization process, beginning with an agent or representative located in a foreign market, to reach the stage of establishing a subsidiary in such a market. This approach also applies psychic distance when companies start to export to neighbor markets due to low costs and cultural similarity. This is a process in which companies gradually involve in the international context.

The above mentioned authors define psychic distance as the sum of the elements that do not allow the information to flow in a market. Among these factors are education, language, business practices and culture. According to Kogut and Singh (1988), the psychic distance predicts the way a company should be established in a market. Authors like Barkema and Vermeulen (1998) have argued that the psychic distances between two markets increases the preference for Greenfield as an entry mode.

On the other hand, Davidson (1980 and 1982) holds that the psychic distance depends on the international experience of a company which easily enters similar markets obtaining in this way resources and technology transfer. Likewise, a company with less experience considers the uncertainty regarding risks and underestimation of earnings.

According to Mallampally and Zimny (2000), FDI is more applicable to services than to products. This is one of the most appropriate entry strategies to internationalize energy services in order to have an initial impact on a foreign market. Additionally, companies are able to recognize and learn about public regulations in the host market, track different projects launched, provide consulting services, and reduce costs and expenses.

Another important aspect that determines or not the entry to new markets is Porter's five forces (2008) which allow specifying the structure of each industry by measuring their competitiveness and profitability. These forces are: (1) buyers or customers bargaining power, which leads to lower prices and demand better quality and services. (2) Suppliers or vendors bargaining power which may become a limiting force, due to high costs that impact the final industry product by increasing prices and reducing the bargaining power. (3) New competitors threat, which can increase their capacity and gain market share in order to push competitive pricing, costs and investment rates. (4) Substitute products which may affect industry profits when there is abundance of such items or services causing pricing reduction. (5) The rivalry among competitors, which is measured by prices, discounts, new product introductions, advertising and improved services (Porter, 2008).

\subsection{Strategies- Entry modes}

The General Agreement on Trade in Services (GATS) describes four modes of supplying services (WTO, 2012). (1) The cross-border supply; here the service provider and the consumer are located in their home country. The service is provided from the territory of the supplier to the customer's territory (Eg. Design of a hydroelectric project sent via an 
electronic source). (2) The consumption abroad. The service is delivered to consumers outside their home country, or provided in the territory of the service provider. (3) The commercial presence, where the service provider is located in the territory of the consumer.. Last (4) The temporal movement of personnel which is a service offered in the territory of the consumer.

The best way to select the most appropriate entry mode depends on the specific situations and conditions of the company to establish an international market (Reis, 2010). According to Fernandez-Stark et al, (2010), a great portion of the main engineering services companies with international operations count on a vertically integrated value chain.

According to Sampson and Snape (1985) in order to decide what type of entry mode will be used, the company should take into account two aspects: deciding where the production plant will be located, and establishing the control level over operations carried out abroad and its corresponding activities. Many service firms profit from experiences that other companies have undergone while internationalizing to reach foreign markets (Bouquet et al., 2004). In this case, a company may choose entry modes with high control to promote their competitive advantages which consist of prior knowledge and consumer needs. This entry mode is commonly selected by legal services, consulting and other professional services.

Additionally, the Greenfield investment proposed by Kumar and Velavan (1994), which describes a company that decides to invest in a new project, is another strategy that can be considered in order to start operations abroad.

According to (Erramilli, 1990), service entry modes can be featured as non-equity modes and equity modes. The non-equity modes of investment do not take into account the equity investment made by an international agent seeking operations and ventures in foreign markets. It is mainly based on contractual agreement and exports. In these types of services professional service firms are included.

On the other hand, the equity modes are formed by wholly owned operations and joint ventures of capital as well as wholly owned subsidiaries (Greenfield and acquisitions). When a firm has a high level of experience in international markets, it entails high risk levels of control and profit returns to the firm taking into account the gradual involvement of the above factors in owned modes (Chu and Erin, 1992).

\section{Comparative Analysis of HMV Ingenieros Ltda's Experience in Chile and Peru.}

Experience is a parameter that allows companies to select the appropriate entry mode to incur in a foreign market. It depends on the degree of control and the contracts that will be obtained in such a market (Dow and Larimo, 2008).

HMV Ingenieros Ltda's experience is analyzed in Chile and Peru. This analysis determines their experience success and how similar strategies could be transferred to the Internationalization Step by Step Model to penetrate the Northern Triangle Market.

\subsection{Psychic distance}

The psychic distance is proportional to the costs involved to enter a market (Johanson \& Vahlne, 1977). In this study, the proximity of the market is categorized into low, medium and 
high. In Chile, costs can be considered as upper-middle, for instance, transport costs are high. The lack of resources in terms of design and consulting services related to energy was a particular need in Chile met by Colombian talent.

Conversely, the psychic distance in Peru shows a medium-low cost taking into account factors such as direct flights, good hotel offer, good transport systems, and else, which facilitates the provision of these services in this market. In this case, HMV Ingenieros Ltda need local commercial agents (Networking) considering its status of foreign company (Poveda, 2012, personal communication, August 8).

\subsection{Experience gained by HMV Ingenieros Ltda.}

HMV Ingenieros Ltda has developed more than 1500 engineering, consulting and turnkey projects. Its experience in Colombia is reflected in 45 million man/hours work in engineering. In Peru and Chile, the firm has $200.000 \mathrm{man} /$ hours work and $10.000 \mathrm{man} /$ hours work, very few in comparison to those worked in its country of origin.

In approaching Chile and Peru, the company assigned, in each country, a representative with experience and knowledge on public bids. They also considered the networking importance of the sector in those countries. In 2008 the pressure and demands of the Peruvian market required not only one representative in this market, but also an office that would Support and manage the projects obtained. Consequently, HMV Ingenieros Ltda established Two subsidiaries in Lima; HMV Ingenieros del Peru and HMV sucursal Peru. In the case of Chile, the company did not start direct operations. Because of their experience and high added value services in other markets, they opened an agency in Santiago in 2011.

In both markets the input speed was positive and relatively fast. Clear rules and regulations facilitated their operations. In each market different needs were met according to the firm's competitive and comparative advantages. In Peru specifically, they began performing design and field supervision of electrical substations. Meanwhile, in Chile they received turnkey electrical substations; a high value added service including everything in the service value chain, from design to project management (Poveda, 2012, personal communication, August 8) (1).

\subsection{Advantages}

The advantages that HMV Ingenieros Ltda had to enter Chile and Peru.were discussed according to Dunning's Eclectic Paradigm (1980), Table 1 shows the results regarding ownership, locational and internalization advantages. 


\section{Table 1 Comparative analysis of HMV Ingenieros Ltda Experience in Chile and Peru-Advantages}

\begin{tabular}{|c|c|c|}
\hline \multirow[b]{2}{*}{ Variables } & \multicolumn{2}{|c|}{ Markets } \\
\hline & Peru & Chile \\
\hline $\begin{array}{l}\text { Ownership specific Advantages } \\
\text { (Benefits and allowances of the company } \\
\text { that permits it committing to production } \\
\text { in another market). }\end{array}$ & $\begin{array}{l}\text { High } \\
\text { There were no other companies in Peru } \\
\text { experts in terms of energy transmission } \\
\text { and generation. Know-how talent was } \\
\text { used to its major extent in order to take } \\
\text { advantage of this market. }\end{array}$ & $\begin{array}{l}\text { High } \\
\text { Chile counted on experience in the energy } \\
\text { transmission and generation field; however, all } \\
\text { systems and information were outdated in } \\
\text { terms of Know-how. } \\
\text { Chile took advantage of Colombia's } \\
\text { experience in order to develop new projects } \\
\text { and update all information systems. }\end{array}$ \\
\hline $\begin{array}{c}\text { Locational specific advantages } \\
\text { (Foreign markets) }\end{array}$ & $\begin{array}{c}\text { High } \\
\text { Energy regulations provided a smooth } \\
\text { atmosphere for FDI. } \\
\text { Approval of professional titles and } \\
\text { provision of working VISAs }\end{array}$ & $\begin{array}{c}\text { High } \\
\text { Energy regulations provided a smooth } \\
\text { atmosphere for FDI. } \\
\text { Approval of professional titles and provision } \\
\text { of working VISAs }\end{array}$ \\
\hline Internalization & $\begin{array}{l}\text { High } \\
\text { Appropriate conditions to open an office } \\
\text { representative. }\end{array}$ & $\begin{array}{l}\text { High } \\
\text { Appropriate conditions to open an office } \\
\text { representative }\end{array}$ \\
\hline $\begin{array}{l}\text { Inputs } \\
\text { From } 1 \text { to } 5 \text { entries caused by } \\
\text { internationalization }\end{array}$ & 4 & 4 \\
\hline $\begin{array}{l}\text { Outputs } \\
\text { From } 1 \text { to } 5 \text { Outputs caused by } \\
\text { internationalization }\end{array}$ & 0 & 0 \\
\hline
\end{tabular}

Source: in partnership with HMV Ingenieros Ltda (Poveda, 2012, personal communication, August 8)

\subsection{Analysis of the business conditions}

Table 2 analyzes the business current state and the strategies followed by HMV Ingenieros Ltda to enter Chile and Peru. When comparing these two experiences, it was observed that the purchasing power that the company had in Chile was higher than the one in Peru which can be categorized as medium in the scale proposed. In the last one, the firm used Greenfield as an entry mode but in both cases they directed operations from headquarters in Colombia. 
Table 2 Comparative analysis of HMV Ingenieros Ltda's Experience in Chile and Peru-Current company conditions

\begin{tabular}{|c|c|c|}
\hline \multirow[b]{2}{*}{ Variables } & \multicolumn{2}{|c|}{ Markets } \\
\hline & Peru & Chile \\
\hline $\begin{array}{c}\text { Purchasing Power } \\
\text { (At internationalization time. Availability of } \\
\text { assets to invest) }\end{array}$ & $\begin{array}{l}\text { Medium } \\
\text { (considering that the firm entered at } \\
\text { different times) }\end{array}$ & $\begin{array}{c}\text { High } \\
\text { (considering that the firm entered at different } \\
\text { times) }\end{array}$ \\
\hline Entry Mode & Greenfield subsidiary & Greenfield subsidiary \\
\hline $\begin{array}{c}\text { Control Level } \\
\text { (Low-Medium-HIgh) }\end{array}$ & $\begin{array}{c}\text { High } \\
\text { Headquarters Control }\end{array}$ & $\begin{array}{c}\text { High } \\
\text { Headquarters Control }\end{array}$ \\
\hline $\begin{array}{c}\text { Risk Exposure } \\
\text { (Low-Medium-High) }\end{array}$ & Medium & Medium \\
\hline FDI Operations & Yes & Yes \\
\hline $\begin{array}{c}\text { Firm Profitability } \\
\text { (Length of time to visualize profits) }\end{array}$ & $\begin{array}{l}\text { Profits in the second year } \\
\qquad \mathbf{1 5 \%}\end{array}$ & $\begin{array}{l}\text { No Profits } \\
\text { Payment against completed project } \\
\mathbf{0 \%}\end{array}$ \\
\hline $\begin{array}{c}\text { National profitability (Colombia) vs } \\
\text { Internacional profitability }\end{array}$ & $\begin{array}{l}\text { Higher profitability in Peru in terms of } \\
\text { Know-how transfer when compared to } \\
\text { Colombia performance. }\end{array}$ & $\begin{array}{l}\text { Higher profitability in Chile in terms of } \\
\text { Know-how transfer, when compared to } \\
\text { Colombia performance. }\end{array}$ \\
\hline $\begin{array}{l}\text { Recovering Profits Period } \\
\text { (Low-Medium-High) }\end{array}$ & Medium & Medium \\
\hline $\begin{array}{c}\text { Channel of income recovery } \\
\text { (Sales) }\end{array}$ & Service sales & Service sales \\
\hline $\begin{array}{c}\text { Services Maturity Offer at the Market } \\
\text { Entry } \\
\text { (Low-Medium-High) }\end{array}$ & High & High \\
\hline
\end{tabular}

Source: in partnership with HMV Ingenieros Ltda (Poveda, 2012, personal communication, August 8).

Higher profits are seen in Chile and Peru than in Colombia since activities in these markets imply more transfer of know-how and added value. HMV Ingenieros Ltda (2012) believes that exports are not easy when competing with the same service. Their strategy focuses on how the engineering service package is designed.and provided. Engineering, Procurement and Construction (EPC) are key factors to acquire added value, offer a range of integrated services from a simple design to its management as well as operation and maintenance of the project.

\subsection{Environment Variables}

Governmental stability and investment conditions in both countries were high, which facilitated the rapid entrance to these markets. When the firm first entered Chile and Peru, competition was medium-low, which favored the quest of potential customers.

Among the challenges that the firm met in these two countries the low operational capacity in qualified work force and the high expenses to transfer Colombian skilled personnel stand out. 
In both countries, governmental regulations and laws in this sector are well issued, which enhance logistics and paperwork. Both markets allow the recognition and approval of professional qualifications making easier the mobility of foreign laborers.

\section{Northern Triangle market characterization}

With the objective of analyzing the different environments of the Nothern Triangle Market as well as its characteristics, opportunities and limitations, a characterization of the market was carried out. Based on the findings of the characterization, competition was evaluated according to Porter's five forces (2008) already mentioned in the literature review section. Finally, an analysis of the psychic distance was done.

\subsection{Social aspects}

Guatemala, Honduras and El Salvador are commonly known as the Northern Triangle Market. They speak the same language and share religious values which are similar to those of Colombia. These aspects enhance dynamics between Colombian and the Northern Triangle companies. On the other hand,, Colombia has 45.239.079 inhabitants, the highest population among the countries studied (Indexmundi, 2012), followed by Guatemala with 14.099 .032 inhabitants, Honduras 8.296.693 inhabitants and finally, El Salvador with 6.090.646 inhabitants.

Culturally, Guatemalans take time to consider any type of negotiation. There is a conscious assessment of suppliers which includes external meetings and other approaches to know each part. They prefer to work with local partners (distributors, agents, representatives) and maintain majority ownership.

Guatemalans are conservative, yet allow time to listen, and sometimes they are ambiguous in their answers. On the other hand, Honduran negotiators do not tolerate aggressive tactics in business, the maintenance of good relations is important, and their making decisions take time since it is a culture that does not take risks and prefer doing a good follow up of negotiation details. Finally, Salvadorans are conservative and formal when negotiating. Maintaining good relations with customers and suppliers in this country is as important, as keeping the quality of contacts and connections. The closure of a business must be respected verbally and accurately throughout the process.

\subsection{Political and legal aspects (2)}

Both Colombia and the countries of the Northern Triangle Market are democratic, which make them stable nations, with low political risk different from other countries ruled by authoritarian political regimes.

In August 2007, Colombia signed a free trade agreement with the countries of the Northern Triangle Market, as a result of six negotiation rounds. Now, these countries recognize national treatment (non-discrimination), preferential access regardless the production site (free trade zones) and tariff reductions. Likewise, these countries agreed on avoiding bans or restrictions on imports and exports of goods through gradual tax incentives. 
Also, the agreement provides special opportunities in public bids offered in these markets.

\section{Regulations}

\section{Guatemala}

In Guatemala the 1441 Act governs the relations between state and workers.. When a firm has more than 10 employees, a special permission from the Labor Ministry shall be provided to operate. The 95-98 immigration policy Decree is the law that regulates the hiring of foreign employees. In Guatemala, it is possible to open a company using $100 \%$ foreign capital. The establishment of a local company takes only about two months, while a foreign firm can take up to six months in order to operate. The Foreign Investment Act is contained in the article 8 of the same decree and must be followed to establish a foreign company in Guatemala. This law guarantees the availability of funds to generate foreign incomes. Similarly, the new foreign company must have identification and a legal representative in Guatemala (Proexport, 2012).

Standards are regulated by the Guatemalan Standards Commission (COGUANOR) of the Economy Ministry. These standards aim at improving trade competitiveness in both goods and services and apply to all sectors.

During the Pequeñas Centrales Hidroeléctricas symposium held in Guatemala in 2010, clear rules applied to building permits (Central Government MEM vs Local Government) were stated.

Article 129 on electricity declared the electrification of the country as a national emergency taking into account the state and municipality plan which allows the private sector participation.

Article 10 specifies that generation and transmission of electricity projects must attach environmental impact assessment that should be carried out by the National Environment Commission (CONAMA) in no more than sixty (60) days. CONAMA shall approve or reject the project. Approval can be provided under general recommendations which must be followed.

Article 14 on hydroelectric power specifies that when the power exceeds $5 \mathrm{MW}$, permission must be sought to the use of water resources which are intended to generate electricity.

The renewable energy projects are encouraged by Decree 52-2003. Articles 1 and 2 express as urgent the rational development of resources and foster investments collected through tax, economic and administrative incentives.

\section{Honduras}

In Honduras, there are tariff reduction incentives to benefit the energy sector. The government offers tax exemptions and import duty benefits for a period of ten (10) to fifteen (15) years. Foreign companies aimed at developing renewable energy projects are benefited by the Customs Act. For instance EPC and construction contracts like HMV Ingenieros Ltda, can take advantage of this act, which makes them more competitive at a lower cost. Additionally, this Act promotes the generation of electricity from renewable resources; it describes sales and compulsory purchase of energy by the National Electricity Company 
(ENEE). Besides, it remarks paid free access to the National Electricity Company (ENEE) or any other agent that commercializes mass produced energy.

\section{El Salvador}

Chapter III of the Salvadoran Commercial Code defines the rules of operation in the energy industry, these should be negotiated under Section 392 by signing an agency or distribution representation contract.

Taxes apply to imports of goods and services; they are 13\% applicable to the tax base.

Major Salvadoran regulations are ruled by the WTO. Standardization, certification and verification are regulated by the National Council for Science and Technology (CONACYT). Salvadoran trade policies are the Salvadoran Mandatory Standards (NSO) and the Salvadoran Recommended Standards (NSR), both regulate the products and services that may affect the life and safety of agents and are freely configurable at the time of negotiation.

$90 \%$ of the employees of a company in this country must be Salvadoran or Central American. 10\% can be foreigners excluding the firm managers (maximum 4). The Labor and Social Ministry authorizes more than $10 \%$ of foreign workers in case of lack of skilled work force in this area. They can only stay for five years, time in which they should employ trained locals on that specific task. The Immigration Department is responsible for authorizing the employment of foreigners.

The Superintendence of Electricity and Telecommunications (SIGET) carries out different activities, such as mitigating the impact risk regarding electricity prices.

\subsection{Economic Aspects}

\subsubsection{General Indicators}

Indexmundi, (2012a), (2012b), (2012c) and (2012d) compares Colombia gross domestic product (GDP), a total of USD\$ 470.7 billion in 2011, with the Northern Triangle countries. Colombia displays the highest GDP, followed by Guatemala USD\$ 74.64 billion, Honduras USD \$ 44.78 billion, and finally El Salvador with USD\$ 35.6 billion. In terms of GDP per capita, Colombia shows the highest (USD\$ 10.100), followed by El Salvador and Honduras with USD \$ 7.600 and USD \$ 4.300 respectively. It is important to note that the development of a country is proportional to higher levels of investment, R\&D and infrastructure projects. These aspects constitute competitive advantages that Colombia has when compared to the Northern Triangle countries. Regarding the unemployment index, a rather different picture can be observed. Colombia has the highest unemployment rate $(10.8 \%)$, followed by El Salvador (7\%), Honduras (4.8\%) and Guatemala (4.1\%). This reflects the lack or abundance of labor supply in the markets. According to the previous information Guatemala and Honduras undergo labor shortage, which Colombia takes as a great opportunity to export skilled labor. On the other hand, in terms of workforce, Colombia has the highest among the four countries with 22.5 million people, followed by Guatemala with 5.1 million, Honduras 3.1 million, and El Salvador with 2.7 million.

With regards to inflation, it is important to note that these four countries have a one digit inflation (projected) in 2011. The country with the highest inflation level is Honduras with 
$7.1 \%$, which leads to a difficult situation when compared to other countries in terms of wages due to the lower purchasing power inflation causes. El Salvador has the lowest rate with $3.4 \%$, followed by Colombia with $4 \%$ (see Table 3 ).

There is no common currency between the Northern Triangle countries and Colombia, so it is necessary to consider the variation in each of the currencies in comparison to the dollar, which is also the official currency in El Salvador. The dollar becomes a reference currency for negotiation in all of these countries. While in Guatemala and Honduras the currency has been stable in recent years, the Colombian peso has tended to revaluation.

Another variable to analyze is the country risk measured by EMBI from Bloomberg (2012). This indicator is important to monitor FDI and determine certain trust levels on investment. In this aspect, Colombia displays the best rate in recent years. Information of this indicator is not available in countries like Guatemala and Honduras.

Table 1 Northern Triangle Characterization-Economic Aspects

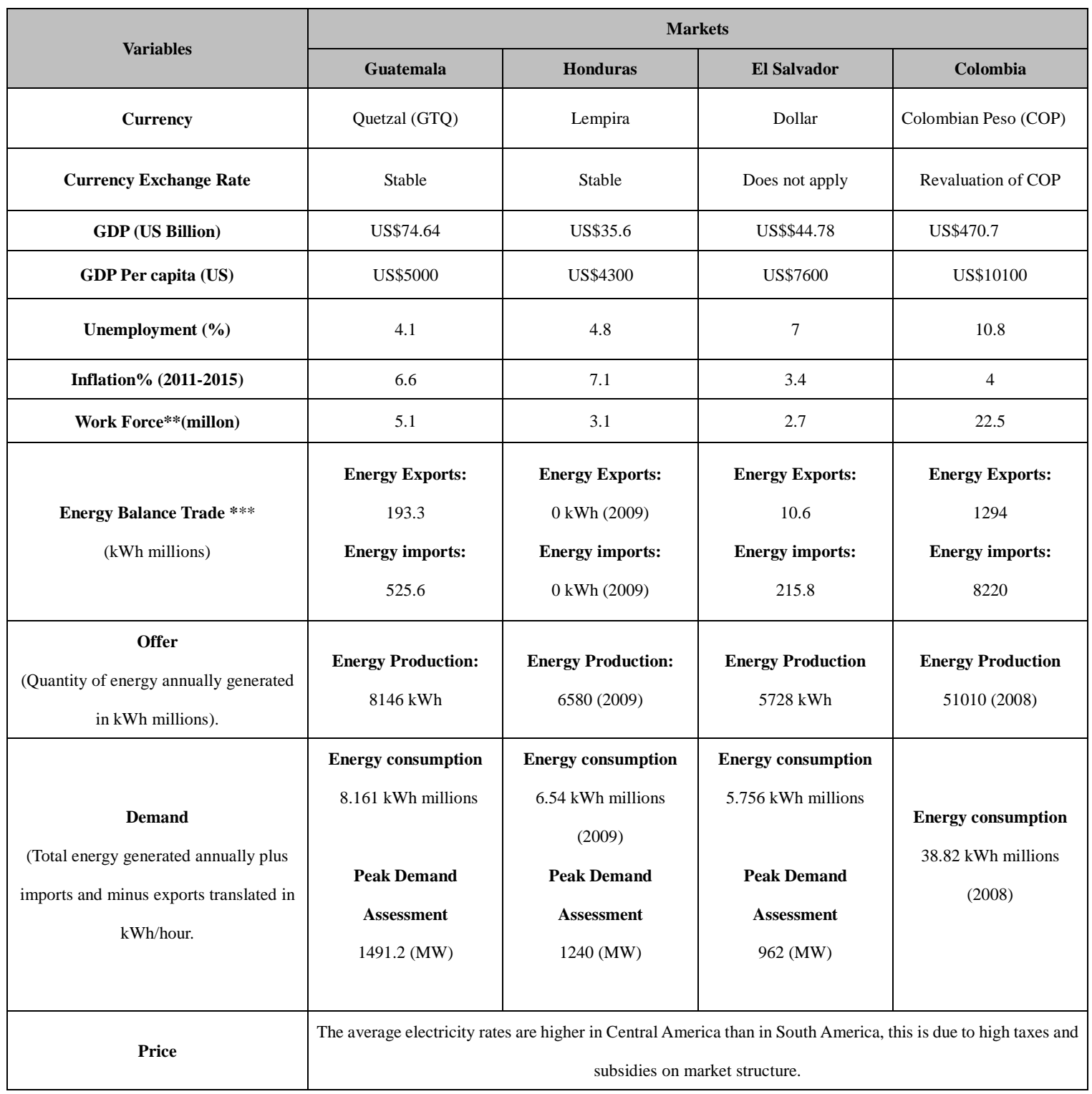

* All the information is of the year 2011, with the exception of trade balance, supply and demand in Honduras which is of 2009.

** This entry represents the total labor force. 
*** This entry is the total exported electricity in kilowatt-hours.

Source: Authors (2012) based on information from Proexport (2012c), (2012d); Indexmundi (2012a), (2012b), (2012c, (2012d), Schwab (2011) and CEPAL (2011b).

Other important variables that make part of the negotiation process that allow visualizing strengths and constraints are reported in Doing Business Report (2012). Generally, it is perceived that Colombia offers the best advantages to negotiate, followed by Guatemala and El Salvador. For example, in terms of construction license, Colombia is the country with the best conditions to carry out processes. In the Northern Triangle, the market with less Requirements and licenses is Honduras, followed by El Salvador and Guatemala.

Property registry is important in this case to analyze the market with greater opportunities to establish an office or appoint a representative. Guatemala has the best advantages in this matter among the countries studied. Also, it offers advantages regarding credits and protecting investors.

\subsubsection{Trade Balance}

The trade balance between Colombia and the Northern Triangle Market reveals a surplus in Colombia favor. Guatemalan surplus reached US\$236.651 billion in 2011. Colombian imports from Guatemala grew $19 \%$ in 2008 and 2010, while exports to Guatemala grew $29 \%$. In Honduras the balance was US\$ 150.8 million (FOB) in 2010, and between January and June 2011 it was US\$ 155.6 million (FOB). In El Salvador, in the same year it was US\$ 93.8 billion (FOB).

Table 3 shows the exports and imports of energy corresponding to each country, and the consumption of the same service and supply in each country. When comparing Colombia to the Northern Triangle countries, Colombia is the country with the highest energy trading exchange which gives it a competitive advantage over other countries in terms of energy generation.

\subsection{Market Size}

\subsubsection{Offer}

In the quest for reaching internationalization to the Northern Triangle market, it is important to mention that HMV Ingenieros Ltda is able to offer engineering and design services related to energy in these countries.

Transmission Lines: HMV Ingenieros Ltda provides engineering, supervision and/or "turnkey" solutions for transmission line projects, with voltage levels of $500 \mathrm{kV}, 230 \mathrm{kV}, 115$ $\mathrm{kV}, 69 \mathrm{KV}$ and $44 \mathrm{KV}$. Using highly specialized computer-modeling programs, some of them developed locally.

High and Extra-High Voltage Substations and Reactive Power Compensation Installations: HMV Ingenieros Ltda also provides "Turnkey" services for substations ranging from $44 \mathrm{KV}$ up to $500 \mathrm{KV}$, applying ANSI (American National Standards Institute) 
and IEC (International Electrochemical Commission) standards to the design process.

Hydroelectric Generation: in this field, they also develop "turnkey" solutions for small hydro generation projects, including feasibility studies, economic and financial assessments, engineering, construction, erection and commissioning. These projects can be developed for an external client or for a company in which HMV Ingenieros Ltda. has equal participation. These services were selected by HMV Ingenieros Ltda based on public bids and projects that have been published in service company websites and government institutions in Guatemala, Honduras and El Salvador.

In 2010, intra-regional energy trade in Central America (imports plus exports) was 1260 GWh, a similar figure to that observed in 2011. The largest transactions correspond to exports from Mexico to Guatemala (525.6 GWh) (CEPAL, 2011a). According to the information above, it can be infered that Mexico is one of the biggest competitors of Colombia mainly because of its proximity and experience.

On the data collected and Porter's force approach (2008), measurement applied to each of the markets studied is proposed (see Table 4). The rivalry between incumbent competitors in these markets is high, as well as the threat of new competitors in Guatemala, Honduras and El Salvador. Colombia has opportunities given the psychic distance principle.

Table 2 Competition Analysis

\begin{tabular}{|c|c|c|c|c|}
\hline \multirow{2}{*}{ Variables } & \multicolumn{4}{|c|}{ Markets } \\
\cline { 2 - 5 } & Guatemala & Honduras & El Salvador & Colombia \\
\hline $\begin{array}{c}\text { Bargaining Power of } \\
\text { Customers }\end{array}$ & High & High & High & High \\
\hline $\begin{array}{c}\text { Bargaining Power of } \\
\text { Suppliers }\end{array}$ & Low & Low & Low & High \\
\hline $\begin{array}{c}\text { Threat of New Entrants } \\
\text { Threat of Substitute } \\
\text { Products }\end{array}$ & Low not apply & Does not apply & Does not apply & High \\
\hline $\begin{array}{c}\text { Competitive Rivalry } \\
\text { within an Industry }\end{array}$ & High & High & High & High \\
\hline
\end{tabular}

Source: Authors in collaboration with HMV Ingenieros Ltda (Poveda, 2012).

According to Consejo de Electrificación de América Central CEAC (2007), in Central America, there is a relationship between Mexico-Guatemala and Panama-Colombia. Figures from Comisión Económica para América Latina y el Caribe (CEPAL, 2011a) show that there has been an increase in investment in power generation, especially in renewable sources. This is evidenced by the annual increase in energy consumption of the Northern Triangle countries in relation to the total consumption in Central America. These institutions present percentages for Honduras, Guatemala and El Salvador 6.5\%, 4.2\% and 1.1\%, respectively, see table 5.

Considering the infrastructure projects in these countries, the installed capacity also increased. The main projects include the hydroelectric and wind power plants in Mesoamerica (102 MW), Honduras and a coal-fired unit (Palmas, 85 MW) in Guatemala. 
Additionally, 13 small and medium hydroelectric projects began operations in Central America with approximately $130 \mathrm{MW}$. Among other remarkable projects are the cogeneration in sugar mills and the use of methane gas at a landfill in El Salvador.

Table 3 Energy Offer and Supply 2011

\begin{tabular}{|c|c|c|}
\hline \multicolumn{3}{|c|}{ Power and Instaled Capacity (MW) } \\
\hline Market & Total & Hydro \\
\hline Centroamérica & 11864.6 & 4959.3 \\
\hline Costa Rica & 2650.2 & 1643.7 \\
\hline El Salvador & 1503.5 & 486.5 \\
\hline Guatemala & 2590.5 & 902.3 \\
\hline Honduras & 1731.0 & 528 \\
\hline Nicaragua & 1093.7 & 105.3 \\
\hline Panamá & 2295.7 & 1293.5 \\
\hline \multicolumn{3}{|c|}{ Net Generation (GWh) } \\
\hline Market & Total & Hydro \\
\hline Central America & 42115.2 & 20623.9 \\
\hline Costa Rica & 9759.6 & 7134.6 \\
\hline El Salvador & 5812.7 & 2075.4 \\
\hline Guatemala & 8146.6 & 4094.2 \\
\hline Honduras & 7126.5 & 2809.6 \\
\hline Nicaragua & 3567.3 & 438.2 \\
\hline Panamá & 7702.5 & 4071.9 \\
\hline
\end{tabular}

Source: Authors based on CEPAL (2011a).

Of the total installed capacity in the Northern Triangle market, Guatemala has the highest level of installed capacity (2590.5 MW) followed by Honduras (1731 MW) and finally El Salvador (1503.05 MW). This suggests a greater potential in the first two countries to develop design and consulting projects related to energy.

\subsubsection{Demand}

CEPAL (2011a) studies show an increase in the energy demand of the Northern Triangle countries, except in Honduras that for 2011 fell 1\% compared to the previous year. Honduras holds the second place (1240 MW) after Guatemala (1491.2 MW), see Table 6. Increased energy demand is linked in, turn, to the demographic growth rate. 
Table 4 Peak Demand Evolution-Northern Triangle

\begin{tabular}{|c|c|c|c|c|c|c|c|}
\hline \multirow{2}{*}{ Year } & Central America & \multicolumn{2}{|c|}{ El Salvador } & \multicolumn{2}{c|}{ Guatemala } & \multicolumn{2}{c|}{ Honduras } \\
\cline { 2 - 8 } & MW & MW & $\%$ & MW & $\%$ & MW & $\%$ \\
\hline 2005 & 5951.8 & 829 & 14 & 1290.1 & 22 & 1014 & 17 \\
\hline 2006 & 6285.1 & 881 & 14 & 1382.6 & 22 & 1088 & 17 \\
\hline 2007 & 6507.4 & 906 & 14 & 1443.4 & 22 & 1126 & 17 \\
\hline 2008 & 6655.4 & 924 & 14 & 1430.1 & 21 & 1205 & 18 \\
\hline 2009 & 6757.4 & 906 & 13 & 1472.5 & 22 & 1203 & 18 \\
\hline 2010 & 6957.8 & 948 & 14 & 1467.9 & 21 & 1245 & 18 \\
\hline 2011 & 7094.7 & 962 & 14 & 1491.2 & 21 & 1240 & 17 \\
\hline
\end{tabular}

According to CEAC (2007) the projected demand growth rate for Central America in 2020 is $4.7 \%$. It is also expected an exponential power demand of $11770 \mathrm{MW}$ and $67853 \mathrm{MW}$ in energy.

Under a scenario of medium energy demand, it is expected for Guatemala to reach, 13775 MW, 11505 MW in Honduras and 8427 MW in El Salvador by 2020, equivalent to a growth rate of $4.2 \%, 3.6 \%$ and $4.0 \%$ respectively.

On the other hand, the forecast corresponding to the medium power demand by the year 2020 indicates that Guatemala, Honduras and El Salvador will grow by 3.7\%, 3.6\% and 4.0\%, respectively. These data are analyzed since these markets have not generated clear figures on the demand and supply of energy related services, hence the demand for energy and power increases and it is reflected in new construction projects for generation and distribution.

Based on the above figures, it can be inferred that Guatemala remains the largest market with advantages in terms of energy service offered to the Northern Triangle.

\subsubsection{Foreign Direct Investment (FDI)}

According to CEPAL (2011b) the energy sector opened in Latin America thanks to FDI done by European and North American multinationals and private national investment.

$62 \%$ of the total electricity production in Central America during the last 10 years has been generated by multinationals such as Gas Natural Fenosa, EPM and AES. Among distributors are state enterprises as ICE-CNFL and ENEE from Costa Rica and Honduras.

Colombia has a negative balance of FDI since local companies that are strong in the area, have bought assets from multinationals that have entered the territory.

Table 7 shows the corporations that have undergone M\&A and have being recognized thanks to their FDI in Latin America, and can be direct competition for HMV Ingenieros Ltda as well as potential customers. ISA and EPM Colombian companies have done FDI in Central America and could ease HMV Ingenieros Ltda entrance to the Northern Triangle Market. 
Table 5 Main Service Actors in Latin America

\begin{tabular}{|c|c|c|c|c|c|c|c|c|c|c|c|c|c|c|}
\hline Company & $\begin{array}{c}\text { Country of } \\
\text { Origin }\end{array}$ & 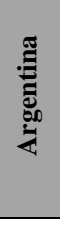 & 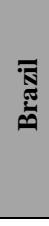 & 䒕 & $\frac{\frac{\pi}{0}}{\frac{0}{0}}$ & 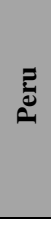 & 寍 & 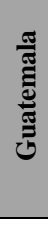 & 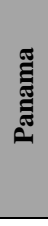 & 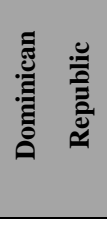 & 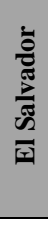 & $\stackrel{n}{\tilde{E}}$ & 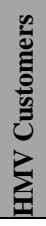 & 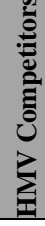 \\
\hline GDF Suez & France & & $\mathrm{X}$ & $X$ & & $\mathrm{X}$ & & & $\mathrm{X}$ & & & & $\mathrm{X}$ & \\
\hline Enel & Italy & $\mathrm{X}$ & $\mathrm{X}$ & $X$ & $X$ & $\mathrm{X}$ & $\mathrm{X}$ & $\mathrm{X}$ & $X$ & & $\mathrm{X}$ & $\mathrm{X}$ & $\mathrm{X}$ & \\
\hline EDF & France & & $\mathrm{X}$ & & & & $\mathrm{X}$ & & & & & & $\mathrm{X}$ & \\
\hline Iberdrola & Spain & & $\mathrm{X}$ & & & & $\mathrm{X}$ & & & & & $\mathrm{X}$ & $\mathrm{X}$ & $\mathrm{X}$ \\
\hline $\begin{array}{c}\text { Gas Natural } \\
\text { Fenosa }\end{array}$ & Spain & & & & $X$ & & $\mathrm{X}$ & & $X$ & $\mathrm{X}$ & & $X$ & $X$ & \\
\hline Duke Energy & USA & $\mathrm{X}$ & $\mathrm{X}$ & & & $\mathrm{X}$ & & $\mathrm{X}$ & & & $\mathrm{X}$ & & & $\mathrm{X}$ \\
\hline AES & USA & $X$ & $\mathrm{X}$ & & $\mathrm{X}$ & & $\mathrm{X}$ & & $\mathrm{X}$ & $\mathrm{X}$ & $\mathrm{X}$ & & $\mathrm{X}$ & \\
\hline EPM & Colombia & & & & $X$ & & & $\mathrm{X}$ & $X$ & & $\mathrm{X}$ & $\mathrm{X}$ & $\mathrm{X}$ & \\
\hline ISA & Colombia & & $\mathrm{X}$ & $\mathrm{X}$ & $X$ & $X$ & & & $X$ & & & $\mathrm{X}$ & $\mathrm{X}$ & \\
\hline
\end{tabular}

Source: Authors based on CEPAL (2011b) and HMV own data.

Latin American countries are considered emerging economies, which makes them more open to FDI in the energy industry. This partially explains the interest of European companies to invest in the region as well as Asian companies such as Japan's Mitsui, Korean Kepco and, Chinese Synohidro and Stated Grid.

\subsection{Market Prices}

Due to the lack of information and studies on services related to energy prices in order to analyze the sector, the evolution of the medium electric rates that can generate a tendency was examined.

CEPAL (2011b) states that the average electricity rates in Central America are higher than in South America, due to high taxes and subsidies of the market structures, a part from the fact that generation sources used in Central America have more thermal components, which are more expensive, while in Colombia most generation components are hydraulic.

According to the Corporación Andina de Fomento (CAF, 2011), a key factor in distribution is that the rates should line up with supply costs. A comparative chart between current price rates in Latin America today shows the region differences not only in terms of schemes, but also in structure. In markets such as Guatemala and El Salvador, the state is almost entirely responsible for services, while in countries like Colombia the responsibility is mixed.

When market prices are analyzed, it is important to consider whether it is a market with subsidized rates or not, since this depends on the final service prices. The CAF (2011) states that governments distribute rates and granted cross subsidies in which some consumers pay higher rates to subsidize others who are not able to pay for the service. In other markets, the state provides subsidies collected through taxes. 
Rates presented in Table 8 shows the instability of values over the years. In 2009, El Salvador had the highest average rate when compared to other markets, while Honduras displayed lower rates.

Table 6 Evolution of the Medium Electric Rates

\begin{tabular}{|c|c|c|c|c|c|c|c|c|}
\hline \multirow{2}{*}{ Market } & \multicolumn{3}{|c|}{ Average Price (USD/kWh) } \\
\cline { 2 - 10 } & $\mathbf{1 9 9 2}$ & $\mathbf{1 9 9 6}$ & $\mathbf{2 0 0 2}$ & $\mathbf{2 0 0 9}$ & $\mathbf{1 9 9 2}$ & $\mathbf{1 9 9 6}$ & $\mathbf{2 0 0 2}$ & $\mathbf{2 0 0 9}$ \\
\hline Colombia & 0.04 & 0.05 & 0.07 & 0.17 & 0.07 & 0.1 & 0.06 & 0.17 \\
\hline Guatemala & 0.05 & 0.08 & 0.08 & 0.17 & 0.07 & 0.11 & 0.07 & 0.16 \\
\hline Honduras & 0.07 & 0.07 & 0.07 & 0.11 & 0.05 & 0.1 & 0.06 & 0.14 \\
\hline El Salvador & 0.04 & 0.09 & 0.09 & 0.19 & 0.04 & 0.12 & 0.11 & 0.18 \\
\hline
\end{tabular}

Source: Authors based on CAF (2011) data

In 2009 a moderate adjustment of $20 \%$ to the consumer prices was implemented. This adjustment was not so high considering that some of the Latin American region currencies had been revaluated and that the cost of the services had been increased. The factors before could have influenced an increase in the dollar prices, the work force cost and the oil prices.

\section{Findings- A Guide to Enter the Northern Triangle Market}

\subsection{Variables Rating}

After analyzing HMV Ingenieros Ltda experience, the variables that were important to the company success in Peru and Chile, and after describing the Northern Triangle market, there was assigned an importance value to each of the variables that determined the opening of a market and its corresponding development in another country.

The variables were selected based on the subsidiary entry mode through Greenfield as an internationalization strategy. The key variables are company's experience, control level in the foreign market, risk exposure, investment climate, regulations to investment, free trade agreements, Government type, GDP, inflation, labor, market size, maturity of the services offered, operational capabilities and human talent.

\subsection{Variables Guide for Energy Related Services (Design and Consulting) in International Markets}

Table 9 comprises a step by step guide to be followed in order to structure information related to an international market, and to come up to conclusions about the opportunities and limitations that an energy related services company might face in a foreign market. 
Table 7 Step by Step Process Suggested for HMV Ingenieros Ltda Internationalization of the Northern Triangle

\begin{tabular}{|c|c|c|c|}
\hline Steps & Description & & Measure \\
\hline $\begin{array}{l}\text { 1. To know psychic } \\
\text { distance and culture }\end{array}$ & $\begin{array}{l}\text { Psychic distance estimated in expenses and } \\
\text { costs from the original market to the } \\
\text { destination market and culture is } \\
\text { characterized. }\end{array}$ & $\begin{array}{r}\text { Geographi } \\
\text { Observation: Cult }\end{array}$ & $\begin{array}{l}\text { roximity to target countries. } \\
\text { were not characterized due to their } \\
\text { similarity }\end{array}$ \\
\hline \multirow{4}{*}{$\begin{array}{l}\text { 2.To analyze HMV } \\
\text { Ingenieros locally and } \\
\text { internationally. }\end{array}$} & \multirow{4}{*}{ Previous cases were analyzed as reference } & Experience & $\begin{array}{c}\text { Man/ Hours worked } \\
\text { Subsidiary number } \\
\text { Operation years } \\
\text { Entry pace } \\
\text { Previously developed services } \\
\text { Number of opened markets }\end{array}$ \\
\hline & & $\begin{array}{l}\text { Competitive } \\
\text { Advantages }\end{array}$ & $\begin{array}{l}\text { Ownership specific advantages } \\
\text { Locational advantages } \\
\text { Internalization } \\
\text { Inputs y outputs }\end{array}$ \\
\hline & & $\begin{array}{c}\text { Current Conditions } \\
\text { Analysis }\end{array}$ & $\begin{array}{l}\text { Power asset acquisition } \\
\text { Entry modes } \\
\text { Control level } \\
\text { Risk Exposure } \\
\text { FDI Operations } \\
\text { Company's profitability } \\
\text { Earning period } \\
\text { Earning recovery means } \\
\text { Income recovery } \\
\text { Services offer maturity }\end{array}$ \\
\hline & & $\begin{array}{c}\text { Environmental } \\
\text { Variables }\end{array}$ & $\begin{array}{c}\text { Political stability } \\
\text { Investment climate } \\
\text { Market competition } \\
\text { Operative capacity } \\
\text { Investment regulations } \\
\text { Titles and professional approval } \\
\text { Factors mobility }\end{array}$ \\
\hline $\begin{array}{l}\text { 3. To analyze foreign } \\
\text { market climate }\end{array}$ & $\begin{array}{c}\text { Analysis of foreign environment to verify } \\
\text { income opportunities and limitations. }\end{array}$ & Social Aspects & $\begin{array}{c}\text { Population } \\
\text { Language } \\
\text { Religion } \\
\text { Commercial customs } \\
\text { Availability of offices and commercial } \\
\text { institutions }\end{array}$ \\
\hline
\end{tabular}




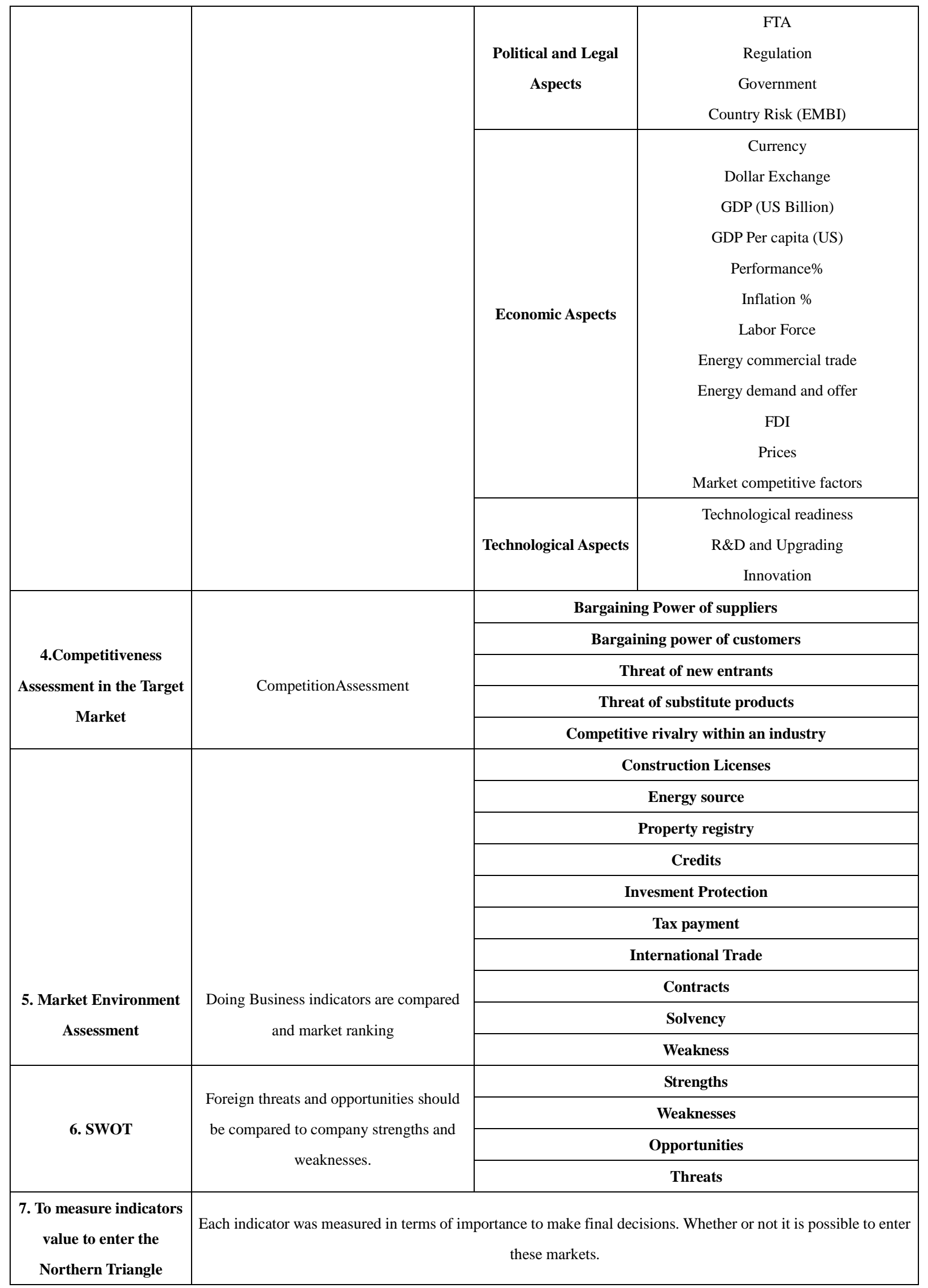

Source: Authors based on Internationalization theories and studied variables 


\section{Conclusions}

Throughout this research, it was observed that HMV Ingenieros Ltda. experience in markets like Chile and Peru was built initially using cross-border delivery (mode 1). The firm faced the need for commercial presence (mode 3) afterwards with the establishment of an office or subsidiary. These factors enhanced trust and control over foreign operations.

HMV Ingenieros Ltda finds business opportunities in the Northern Triangle market thanks to the following factors:

- Competitive and comparative advantages in areas of knowledge and experience when compared to other firms in the Northern Triangle market.

- Increasing energy demand forecast for the next years. This results in numerous infrastructure projects to meet foreign market energy needs.

- Likewise, in the international arena, renewable energy is highly supported by local governments, providing tariff incentives to companies that develop such projects.

- A trade representative figure while exploring a market is crucial in this type of services (design and consulting services related to energy).

A multidisciplinary working group must be selected by the firm in order to internationalize its services. The group will be in charge of controlling foreign operations and leading the organizational culture to each possible subsidiary opened abroad. The integration of a group of experts from the target market is important as well. These leaders know and recognize local idiosyncrasy, culture, and domestic laws and regulations.

Despite the opportunities found in the Northern Triangle market, it is essential to recognize the lack of skilled personnel, operating in these markets, unable to lead projects on design and consulting services related to energy. HMV Ingenieros Ltda must be aware of the competition among multinational companies already established in the Northern Triangle. Based on energy demand and GDP, out of these markets, Guatemala has the highest growth potential for these types of services followed by Honduras.

Finally, it was concluded that transferring labor force from Colombia to any of the Northern Triangle markets is not an easy task due to market regulations and laws in those countries.

\section{Notes}

(1) All the information about the Comparative analysis of HMV Ingenieros Ltda's Experience in Chile and Peru described in section 3, was obtained in August 2012, in a personal communication with Edgar Poveda, Vice-President at HMV Ingenieros Ltda

(2) All political and legal information was retrieved from Proexport, 2012a, 2012c, 2012d, 2012e; Indexmundi 2012a, 2012b, 2012c, 2012d; Oficina Comercial de España en Colombia, 2011; Bloomberg, 2012 and Curso Pequeñas Centrales Hidroeléctricas, 2010. 


\section{References}

Barkema, H. G., \& Vermeulen, F. (1998). International expansion through start-up or through acquisition: A learning perspective. Academy of Management Journal, 41(1), 7-26.

Bastidas, L. M., Montoya, S. F., \& Velasquez, J. D. (2008). ¿Hacia dónde irán los sectores eléctricos de los países de la región Andina? Tendencias posibles, 21(35), 307-325.

Bouquet, C., Hébert, L. \& Delios A. (2004). Foreign expansion in service industries: Separability and human capital intensity. Journal of Business Research, 57(1), 35-46.

Chu, W., \& Erin, A. (1992). Capturing ordinal properties of categorical dependent variables: A review with application to modes of foreign entry. International Journal of

Research in Marketing, 9, 149-160.

Comisión Económica para América Latina y el Caribe (CEPAL). (2011a). Centroamérica: Estadísticas de producción del subsector eléctrico, 1-39.

Comisión Económica para América Latina y el Caribe (CEPAL). (2011b). La inversión extranjera directa en energía eléctrica en América Latina y el Caribe, 4, 157-194.

Consejo de Electrificación de América Central CEAC. (2007). Plan indicativo regional de expansión de la generación periodo 2007-2020. 1-122.

Comisión Económica para América Latina y el Caribe (CEPAL). (2011a). Centroamérica: Estadisticas de producción del subsector eléctrico, 1-39.

Comisión Económica para América Latina y el Caribe (CEPAL). (2011b). La inversión extranjera directa en energía eléctrica en América Latina y el Caribe, 4, 157-194.

Corporación Andina de Fomento (CAF). (2011). La Infraestructura en el Desarrollo Integral de América Latina. Diagnóstico estratégico y propuesta para una agenda prioritaria. Energía eléctrica. 1-76.

Curso Pequeñas Centrales Hidroeléctricas. (2010). Recursos para el desarrollo de pequeñas centrales hidroeléctricas en América Latina. Seminario realizado del 28 de noviembre al 4 de diciembre de 2010, La Antigüa, Guatemala.

Datamonitor.(2009). Global construction \& engineering profile. Datamonitor Report, 1-31. Davidson, W.H. (1980). The location of foreign investment activity. Journal of International Business Studies, 9-23.

Davidson, W.H. (1982). Global strategic management. New York: John Wiley \& Sons.

Doing Business. (2012). Informe anual. Retrieved from: http://www.doingbusiness.org/

Dow, D., \& Larimo, J. (2008). Psychic distance, international experience and establishment mode. Melbourne Business School, 1-31.

Dunning, J. H. (1980). Toward An Eclectic Theory of International Production: some empirical tests. Journal of International Business Studies, University of Reading, 12-33.

Erramilli, M. K. (1990). Entry mode choice in service industries. International Marketing Review, 7(5): 50-62.

Fernandez-stark, K., Bamber, P., \& Gereffi, G. (2010). Engineering services in the Americas. Center on globalization, governance \& competitiveness, Duke University, 1-99.

HMV Ingenieros Ltda. (2008). Nosotros.

Retrieved from: http://www.h-mv.com/Inicio/tabid/36/language/en- US/Default.aspx

Indexmundi. (2012a). Honduras. Retrieved from: http://www.indexmundi.com/es/honduras/

Indexmundi. (2012b). Guatemala. Retrieved 
http://www.indexmundi.com/es/guatemala/

Indexmundi. (2012c). $\quad E l \quad$ Salvador. $\quad$ Retrieved from http://www.indexmundi.com/es/el_salvador/

Indexmundi. (2012d). Colombia. Retrieved from: http://www.indexmundi.com/es/colombia/

Johanson, J. \& Vahlne, J.-E. (1977). The internationalization process of the firm: A model of knowledge development and increasing foreign market commitments. Journal of International Business Studies, 8(1), 23-32.

Kogut, B., \& Singh, H. (1988). The effect of national culture on the choice of entry mode. Journal of International Business Studies, 19(3), 411-432.

Kumar, V., \& Velavan, S. (1994). A Contingency framework for the mode of entry decision. Journal of World Business, 53-72.

Mallampally, P., \& Zimny, Z. (2000). Globalization of services. In L. Nachum \& Y. Aharoni (Ed.), Foreign direct investment in services. Trends and patterns. Some implications for theories (pp. 27-49).

Organización Mundial del Comercio. (2012). Definición del comercio de servicios $\quad y \quad d e$ los modos de suministro. Retrieved from: http://www.wto.org/spanish/tratop_s/serv_s/cbt_course_s/c1s3p1_s.htm

Porter, M. E. (2008). The five competitive forces that shape strategy. Harvard Business Review, 78-93.

Primo, C. A. (1996). The impact of the internationalization of services on developing countries. Finance \& Development, 33(1), 34-37.

Proexport. (2012a). Perfil El Salvador. Retrieved from: http://www.proexport.com.co/sites/default/files/Perfil_El_Salvador.pdf

Proexport. (2012b). Perfil Honduras. Retrieved from: http://www.proexport.com.co/sites/default/files/Perfil_honduras.pdf.

Proexport. (2012c). Guía para exportar a Guatemala. Retrieved from: http://www.proexport.com.co/site1s/default/files/Como_exportar_a_Guatema la.pdf.

Proexport. (2012d). Guía para exportar a El Salvador. Retrieved from: http://www.proexport.com.co/sites/default/files/Como_exportar_a_El_Salvad or.pdf

Proexport. (2012e). Oportunidades Comerciales en el Triángulo Norte: Guatemala, El Salvador, Honduras. Retrieved from: http://www.proexport.com.co/memorias/seminario-oportunidadescomerciales-con-am\%C3\%A9rica

Reis, H. M. P. (2010). Internationalization models study on larger international contractors from U.S.A. and China. International Journal of Arts and Sciences, 3(13), 155-186.

Rudnick, H. (1998). Competitive markets in electricity supply: Assessment of the South American experience. Revista Abante, 1(2), 189-211.

Ruiz, A. (2010). La cooperación e integración energética en América Latina y el Caribe. puente@europa,8 (1),62-67.

Sampson, G. P., \& Snape, R. H. (1985). Identifying the issues in trade in services. The World Economy, 8(2) 171-182.

Schwab, Klaus. (2011).The global competitiveness report 2011-2012. World Economic 
Forum, 1-544.

US Census Bureau. (2012). North American Industry Classification System (NAICS).

Retrieved from: http://www.census.gov/cgi-bin/sssd/naics/naicsrch 